\title{
Solubility enhancement, physicochemical characterization and formulation of fast-dissolving tablet of nifedipine-betacyclodextrin complexes
}

\author{
Swati Changdeo Jagdale ${ }^{1, *}$, Vinayak Narhari Jadhav', Aniruddha Rajaram Chabukswar ${ }^{2}$, \\ Bhanudas Shankar Kuchekar ${ }^{2}$ \\ ${ }^{1}$ Department of Pharmaceutics, MAEER's Maharashtra Institute of Pharmacy, Maharashtra, India, ${ }^{2}$ Department of \\ Pharmaceutical Chemistry, MAEER's Maharashtra Institute of Pharmacy, Maharashtra, India
}

\begin{abstract}
The main objective of the study was to enhance the dissolution of nifedipine, a poorly water soluble drug by betacyclodextrin complexation and to study the effect of the preparation method on the in vitro dissolution profile. The stoichiometric ratio determined by phase solubility analysis for inclusion complexation of nifedipine with $\beta$-cyclodextrin was $1: 1$. Binary complex was prepared by different methods and was further characterized using XRD, DSC and FT-IR. A saturation solubility study was carried out to evaluate the increase in solubility of nifedipine. The optimized complex was formulated into fast-dissolving tablets by using the superdisintegrants Doshion P544, pregelatinized starch, crospovidone, sodium starch glycolate and croscarmellose sodium by direct compression. Tablets were evaluated for friability, hardness, weight variation, disintegration and in vitro dissolution. Tablets showed an enhanced dissolution rate compared to pure nifedipine.
\end{abstract}

Uniterms: Fast-dissolving tablets. Nifedipine/dissolution. $\beta$-ciclodextrin/complexation. Superdisintegrants.

Este estudo teve por objetivo principal incrementar a dissolução do nifedipino, fármaco pouco solúvel em água, por meio de sua complexação com $\beta$-ciclodextrina e estudar o efeito do método de preparação sobre o perfil de dissolução in vitro. A razão estequiométrica, determinada por ensaio de solubilidade de fase, para a complexação de nifedipino por inclusão em $\beta$-ciclodextrina foi 1:1. O complexo binário foi preparado por diferentes métodos, sendo caracterizado utilizando-se difratometria de raios X(XRD), calorimetria diferencial de varredura (DSC) e espectroscopia no infravermelho com transformada de Fourier (FT-IR). Realizou-se estudo de solubilidade de saturação para avaliar o incremento da solubilidade do nifedipino. O complexo otimizado foi formulado em comprimidos de dissolução rápida preparados por compressão direta, nos quais se utilizaram os superdesintegrantes Doshion P544, amido pré-gelatinizado, crospovidona, amidoglicolato de sódio e croscarmelose sódica. Os comprimidos, que foram avaliados quanto à friabilidade, dureza, variação de peso, desintegração e dissolução in vitro, apresentaram taxa de dissolução superior à do nifedipino pura.

Unitermos: Comprimidos/de dissolução rápida. Nifedipino/dissolução. $\beta$-ciclodextrina/complexação. Superdesintegrantes.

\section{INTRODUCTION}

Nifedipine is an oral calcium-channel blocking agent, widely used in the treatment of angina pectoris and hypertension. Nifedipine is a poorly water-soluble

*Correspondence: Swati Changdeo Jagdale. Department of Pharmaceutics, MAEER's Maharashtra Institute of Pharmacy, S.No 124, MIT Campus, Kothrud, Pune- 411 038, Maharashtra, India. E-mail: jagdaleswati@rediffmail.com drug and its oral bioavailability is very low. Diseases like angina, asthma, epilepsy etc. require immediate drug response to manage the disease condition. Improvement of the aqueous solubility of poorly water-soluble drugs is one of the important factors for the enhancement of absorption and obtaining adequate oral bioavailability (Hiroyuki et al., 2009).

Cyclodextrins (CDs) have been used extensively as additives to increase the solubility of poorly water-soluble 
organic compounds, by the formation of an inclusion complex between the host cyclodextrin molecules and guest molecules. The resulting noncovalent inclusions or host-guest complexes are of current scientific and technological interest for their peculiar physical, chemical and biological properties. Such noncovalent associations can actually improve the guest's water solubility, bioavailability and stability, as well as regulate the release of the guest molecules (Chao et al., 2008).

The dissolution of a drug can also be influenced by disintegration time of tablets. Faster disintegration of tablets delivers a fine suspension of drug particles resulting in a higher surface area and faster dissolution. Most commonly used methods to prepare fast dissolving tablets are; freeze-drying, tablet moulding and direct compression methods. Lyophilized tablets possess a very porous structure, which causes quick penetration of saliva into the pores when placed in the oral cavity. Moulded tablets dissolve completely and rapidly. However lack of strength and taste masking are of great concern. Main advantages of direct compression are low manufacturing cost and high mechanical integrity of tablets. Therefore, direct compression appears to be better option for manufacturing of tablets. Fast disintegrating tablets prepared by the direct compression method, in general, are based on the action established by various superdisintegrants. The effect of functionality differences in superdisintegrants on tablet disintegration has been previously studied (Setty, 2008).

\section{MATERIAL AND METHODS}

\section{Material}

Nifedipine was a generous gift from Alkem Lab (Mumbai). The drug was stored in an amber glass container wrapped with aluminium foil and kept in a refrigerator at $5-7^{\circ} \mathrm{C}$. The complexing agent betacyclodextrin (BCD) was purchased from Gangwal chemicals, Mumbai. Microcrystalline cellulose (MCC), mannitol, aspartame, magnesium stearate, orange flavor, pregelatinized starch, sodium starch glycolate, crospovidone, Doshion P 544 and croscarmellose sodium were procured from SD fine chemicals, Mumbai. All other chemicals and solvents used were of pharmaceutical and analytical grade. Double distilled water was used throughout the study for all the experimental procedures.

\section{Phase solubility study}

Phase solubility studies were carried out at room temperature, in triplicate and according to the method reported by Higuchi and Connors (Higuchi, 1965). An excess amount of nifedipine was added to double distilled water containing various concentrations of $\beta-C D(0.02-$ $0.1 \mathrm{M}$ ) in a series of stoppered conical flasks and shaken for $48 \mathrm{~h}$ on a rotary flask shaker. The suspensions were filtered through Whatman filter paper and assayed for nifedipine using a UV spectrophotometer (Varian Cary 100 , Australia) at $238 \mathrm{~nm}$ against a blank prepared using the same concentration of $\beta-C D$ in double distilled water.

\section{Preparation of nifedipine: $\beta-C D$ complexes $[1: 1$ Molar ratio]}

The solid complexes of nifedipine and $\beta$-CD (1:1 molar ratio) were prepared by the following method-

\section{Kneading method (Kn)}

Drug and $\beta-C D$ was triturated in a mortar with a small volume of water-methanol solution. The thick slurry was kneaded for $45 \mathrm{~min}$ and then dried at $40{ }^{\circ} \mathrm{C}$. Dried mass was pulverized and sieved through a (\#100) mesh (Nalluri et al., 2005).

\section{Coevaporation method (COE)}

The aq. solution of $\beta-C D$ was added to an alcoholic solution of drug. The resulting mixture was stirred for 1 $\mathrm{hr}$ and evaporated at a temp of $45^{\circ} \mathrm{C}$ until dry. The dried mass was pulverized and sieved through a (\#100) mesh (Nalluri et al., 2005).

\section{Co-grounding (COG)}

Drug was triturated with a minimal quantity of methanol in a glass mortar until dissolved. $\beta-C D$ was then added and the suspension triturated rapidly at room temperature until solvent had evaporated (Friedrich, 2005).

\section{Freeze -Drying Method (FD)}

Physical mixtures of drug and $\beta-C D$ at a molar ratio of $1: 1$ were added to $500 \mathrm{ml}$ double distilled water and stirred for 5 days. The suspension was freeze-dried (ilshin ${ }^{\circledR}$ freeze Dryer), and the freeze-dried complex thus produced was pulverized and sieved through a $(<38 \mu \mathrm{m})$ mesh (Tsinontides et al., 2004).

\section{Melting method (MELT)}

A melting method was used for the preparation of 
drug- $\beta$-CD complex. The drug- $\beta$-CD ratio (1:1 Molar) was accurately weighed, mixed in s crucible, and the mixture kept for melting in a water bath with constant stirring. The mixture was cooled slowly at room temperature. The product was placed in desiccators. The solidified product was transferred to a clean mortar, triturated and passed through sieves no.16 and 20 (Van et al., 1998).

\section{Physical mixture (PM)}

The physical mixtures of nifedipine and $\beta-\mathrm{CD}[1: 1$ molar ratio] were obtained by mixing pulverized powder (\#100) together in pestle and mortar (Nalluri et al., 2005).

\section{Spray Drying method (SPD)}

A mixture of drug and $\beta-C D$ was dissolved in 250 $\mathrm{ml}$ of water. The resultant solution was spray dried using a spray dryer. The spray drying was done under the following sets of conditions; air flow rate at $400 \mathrm{Nl} / \mathrm{h}$, spray nozzle with a diameter $0.7 \mathrm{~mm}$ under an atomization pressure of $2 \mathrm{~kg} / \mathrm{cm}^{2}$ with a feed rate of $4 \mathrm{~mL} / \mathrm{min}$. The inlet temperature was kept at $120^{\circ} \mathrm{C}$ and out let temperature at $90{ }^{\circ} \mathrm{C} \pm 2{ }^{\circ} \mathrm{C}$. The vacuum in the system was $60 \mathrm{mmWc}$ and the aspiration rate was $40 \mathrm{~m}$ Bar. The product thus obtained was collected, packed, doubly wrapped in aluminum foil and stored in a desiccator until further use (Patil et al., 2010).

\section{Evaluation of solid complexes}

\section{Determination of drug content}

Drug: $\beta$-CD complex equivalent to $10 \mathrm{mg}$ of drug was stirred with $100 \mathrm{ml}$ of methanol for 60 minutes. Subsequently, the solution was filtered and treated as stock solution containing $100 \mu \mathrm{g} / \mathrm{mL}$ drug. From this stock solution a concentration of $10 \mu \mathrm{g} / \mathrm{mL}$ was prepared and the drug content determined using the calibration curve of pure drug in methanol, analyzed spectrophotometrically at $238 \mathrm{~nm}$ using methanol as the blank (Shirsand, 2010).

\section{Saturation solubility studies}

A saturation solubility study was carried out to determine increase in the solubility of pure nifedipine compared with the PM and inclusion complexes. Excess amount of the drug, PM and inclusion complexes were added to the $250 \mathrm{~mL}$ conical flasks containing $25 \mathrm{~mL}$ of double distilled water. The sealed flasks were shaken for $24 \mathrm{~h}$ at room temperature followed by equilibrium for three days. Aliquots were then withdrawn through Whatman filter paper. The concentration of nifedipine was determined by
UV spectrophotometer at $238 \mathrm{~nm}$ (Vanshiv, 2008).

\section{Characterization of nifedipine: $\beta-C D(1: 1)$ complexes}

\section{UV spectroscopic study}

Complex formation between nifedipine and $\mathrm{CD}$ was studied by the UV spectroscopic method. 10mg amounts of nifedipine were weighed accurately and dissolved in $100 \mathrm{ml}$ of methanol, diluted suitably and spectra of drug recorded at $238 \mathrm{~nm}$. The same method was used only nifedipine - CD complex equivalent to $10 \mathrm{mg}$ of nifedipine were weighed accurately and dissolved in $100 \mathrm{~mL}$ of methanol, diluted suitably and spectra of complexes recorded at $238 \mathrm{~nm}$. The change in the absorbance of drug in the complexes was recorded.

\section{Fourier Transform Infrared spectrophotometry [FT-IR]}

FT-IR has been employed as a useful tool to identify drug excipient interaction. Samples were analyzed by the potassium bromide pellet method in an IR spectrophotometer (Varian, Australia) in the region from 4000 to $400 \mathrm{~cm}^{-1}$. Complex formation was evaluated by comparing the IR spectra of the solid complex and that of the drug.

\section{Powder X-ray Diffractometry [PXRD]}

The powder X-ray diffraction technique has been extensively utilized along with DSC to study the interaction between drug and $\beta$-CD. The diffraction studies were carried out on a powder X-ray diffractometer (STOESTADI-P). The samples were rotated during data collection to reduce orientation effects. PXRD patterns of solid complex, pure drug, and $\beta-\mathrm{CD}$ were recorded between $2 \theta=5$ to $50^{\circ}$ at $40 \mathrm{kV}$ and $30 \mathrm{~mA}$.

\section{Differential Scanning Calorimetry [DSC]}

Differential scanning calorimetry (DSC) has been one of the most widely used calorimetric techniques to study the solid state interaction of drug with $\beta$-CD (Ramana et al.,2008). Samples of the solid complexes, pure drug, and $\beta-C D$ were taken in flat-bottomed aluminium pans and heated over a temperature range of 25 to $300^{\circ} \mathrm{C}$ at a constant rate of $10 \% \mathrm{~min}$ with purging of nitrogen $(50 \mathrm{ml} / \mathrm{min})$ using alumina as a reference standard in a differential scanning calorimeter (DSC-7, Perkin Elmer).

\section{In-vitro dissolution studies}

Drug release studies were performed in triplicate at $37 \pm 0.5{ }^{\circ} \mathrm{C}$ employing USP apparatus II at $75 \mathrm{rpm}$. The dissolution study was carried out in two dissolution media (Phosphate buffer of pH 6.8 and double distilled water). 
Dissolution studies were performed on pure drug $(10 \mathrm{mg})$ and the complexes containing an equivalent amount of the drug. Aliquots of the periodically withdrawn samples $(5 \mathrm{~mL})$ were analyzed spectrophotometrically at $238 \mathrm{~nm}$, and replaced with an equal volume of plain dissolution medium (Naveen, 2007).

\section{Formulation of tablets}

Freeze-dried complex was selected for the formulation of tablets. Tablets containing $42.8 \mathrm{mg}$ of drug: $\beta-C D$ freeze dried complex equivalent to $10 \mathrm{mg}$ of drug were prepared by the direct compression method and the various formulae used in the study are shown in Table I. The drug, diluents, superdisintegrant and sweetener were passed through sieve $\neq 40$. All the above ingredients were properly mixed together (in a polybag). Magnesium stearate was passed through sieve $\neq 80$, mixed, and blended with the initial mixture in a polybag. The powder blend was compressed into tablets on an 8-station Rotary Tablet Machine Minipress-II (Rimek Ltd.). The weight of tablets in each batch was kept constant (Setty, 2008).

\section{Evaluation of fast-dissolving tablets}

\section{Evaluation of powder blend}

The powder blend was evaluated for flow properties. Different tests carried out included bulk density, tapped density, compressibility index, and Hausner ratio (Lachman, 1991).

TABLE I - Formulae used in the preparation of tablets
Bulk Density $\left(V_{b}\right)=\frac{\text { Mass }}{\text { Bulk Volume }}$

Tapped Density $\left(V_{t}\right)=\frac{\text { Mass }}{\text { TappedVolu me }}$

Hausner's Ratio $(H)=\frac{V_{t}}{V_{b}}$

$\operatorname{Carr}^{\prime} \operatorname{s} \operatorname{Index}(I)=\frac{V_{t}-V_{b}}{V_{t}} \times 100$

\section{Evaluation of tablets}

Hardness of the tablets was evaluated using a Monsanto hardness tester. The friability of tablets for each batch was determined using an automated USP Roche friabilator. The Tablets were subjected to tests for uniformity of drug content, and uniformity of mass of single dose preparation as per US Pharmacopeia (USP, 2009).

In vitro disintegration, wetting time and water absorption ratio studies

For determination of in vitro disintegration time (D.T.), one tablet was placed in a beaker containing $10 \mathrm{ml}$ of phosphate buffer at $\mathrm{pH} 6.8$ and the time required for complete dissolution (with mild shaking) was measured (Kimura, 1992). On the other hand, the wetting time was measured as follows: a sample of the final tablet was placed in a petri dish (10 cm in diameter) containing $10 \mathrm{~mL}$

\begin{tabular}{|c|c|c|c|c|c|c|c|c|c|c|c|c|c|c|c|c|}
\hline Ingredients (mg) & Control & DO I & DO II & DO III & PGS I & PGS II & PGS III & CRP I & CRP II & CRP III & SSG I & SSG II & SSG III & CCS I & CCS II & CCS III \\
\hline Drug : CD & 42.8 & 42.8 & 42.8 & 42.8 & 42.8 & 42.8 & 42.8 & 42.8 & 42.8 & 42.8 & 42.8 & 42.8 & 42.8 & 42.8 & 42.8 & 42.8 \\
\hline \multicolumn{17}{|l|}{ Complex } \\
\hline MCC PH 102 & 83.2 & 83.2 & 83.2 & 83.2 & 83.2 & 83.2 & 83.2 & 83.2 & 83.2 & 83.2 & 83.2 & 83.2 & 83.2 & 83.2 & 83.2 & 83.2 \\
\hline Mannitol & 120 & 104.4 & 99.2 & 94 & 104.4 & 99.2 & 94 & 104.4 & 99.2 & 94 & 104.4 & 99.2 & 94 & 104.4 & 99.2 & 94 \\
\hline Doshion P544 & - & 15.6 & 20.8 & 26.0 & - & - & - & - & - & - & - & - & - & - & - & - \\
\hline Crospovidone & - & - & - & - & - & - & - & 15.6 & 20.8 & 26.0 & - & - & - & - & - & - \\
\hline Croscarmellose & - & - & - & - & - & - & - & - & - & - & - & - & - & 15.6 & 20.8 & 26.0 \\
\hline \multicolumn{17}{|l|}{ Sodium } \\
\hline $\begin{array}{l}\text { Pregelatinized } \\
\text { starch }\end{array}$ & - & - & - & - & 15.6 & 20.8 & 26.0 & - & - & - & - & - & - & - & - & - \\
\hline $\begin{array}{l}\text { Sodium starch } \\
\text { glycolate }\end{array}$ & - & - & - & - & - & - & - & - & - & - & 15.6 & 20.8 & 26.0 & - & - & - \\
\hline Aspartame & 5 & 5 & 5 & 5 & 5 & 5 & 5 & 5 & 5 & 5 & 5 & 5 & 5 & 5 & 5 & 5 \\
\hline $\begin{array}{l}\text { Magnesium } \\
\text { stearate }\end{array}$ & 4 & 4 & 4 & 4 & 4 & 4 & 4 & 4 & 4 & 4 & 4 & 4 & 4 & 4 & 4 & 4 \\
\hline Orange Flavor & 5 & 5 & 5 & 5 & 5 & 5 & 5 & 5 & 5 & 5 & 5 & 5 & 5 & 5 & 5 & 5 \\
\hline Total ( mg) & 260 & 260 & 260 & 260 & 260 & 260 & 260 & 260 & 260 & 260 & 260 & 260 & 260 & 260 & 260 & 260 \\
\hline
\end{tabular}

DO-Doshion, PGS-Pregelatinized starch, CRP-Crospovidone, SSG-Sodium starch Glycolate, CCS-Croscarmellose sodium, I-6\%, II- $8 \%$, III-10\% 
of water at room temperature. The wetting time is the period necessary for complete wetting of the tablet. The wetted tablet was then weighed. Water absorption ratio, $R$, was determined according to the following equation:

$R=\frac{W_{a}-W_{b}}{W_{a}} \times 100$

where $W_{a}$ and $W_{b}$ are the weights before and after water absorption, respectively (Shirsand et al., 2008).

In vitro dissolution

In vitro dissolution studies of fast-dissolving tablets were performed by using an USP type II apparatus as specified in the USP at $75 \mathrm{rpm}$, using dissolution media (distilled water/ phosphate buffer of $\mathrm{pH}$ 6.8) maintained at $37 \pm 0.5{ }^{\circ} \mathrm{C}$. Aliquots of dissolution medium were withdrawn at specific time intervals and filtered. Absorption of filtered solution was checked by UV spectroscopy, and drug content was determined from standard calibration curves. The dissolution rate was studied for all formulations designed (Kuchekar, 2001).

\section{Assay method}

Twenty tablets were weighed accurately and powdered. Tablet powder equivalent to $10 \mathrm{mg}$ of drug was stirred with $100 \mathrm{~mL}$ of methanol for 60 minutes, then the solution was filtered and treated as stock solution containing $100 \mu \mathrm{g} / \mathrm{mL}$ drug. From this stock solution, further dilutions were done for each formulation. Absorbances were measured and the concentration of drug in the tablet determined using the calibration curve of pure drug in methanol, analyzed spectrophotometrically at $238 \mathrm{~nm}$ using methanol as the blank.

$$
\% \text { Assay }=\frac{\text { Absorbance of Sample }}{\text { Absorbance of Std. }} \times 100
$$

\section{Stability testing}

Temperature dependent stability studies were carried out on the optimized batches including DO II, CRP II and CCS II. Batches were packed in Alu-Alu pouches and stored under the following conditions for a period as prescribed by ICH guidelines for accelerated studies in stability chambers (Thermolab).

(i) $30 \pm 2{ }^{\circ} \mathrm{C}$ and $\mathrm{RH} 65 \% \pm 5 \%$

(ii) $40 \pm 2{ }^{\circ} \mathrm{C}$ and $\mathrm{RH} 75 \% \pm 5 \%$

The tablets were withdrawn after a period of 7,14 days, 1, 2 and 3 months and analyzed for visual defects, hardness, friability, disintegration time, thickness, average weight and percentage assay (Marais, 2003).

\section{Infrared spectroscopy study of tablets}

IR studies were carried out using potassium bromide discs. The reference standard was compared with that of the formulation.

\section{Data analysis}

\section{Phase-solubility studies}

The values of apparent stability constant, Ks, between each drug-carrier combination were computed from the phase-solubility profiles, as described below:

$$
K s=\frac{\text { Slope }}{\text { Intercept }(1-\text { Slope })}
$$

The values of Gibbs free energy of transfer, $\Delta \mathrm{Go}_{\mathrm{tr}}$, of Nifedipine from aqueous solution of the carriers were calculated according to the following relationship:

$$
\Delta G o_{t r}=-2.303 R T \cdot \log \frac{S_{o}}{S_{s}}
$$

Where, $\mathrm{S}_{\mathrm{o}}$ and $\mathrm{S}_{\mathrm{s}}$ are the molar solubilities of nifedipine in $1 \% \mathrm{w} / \mathrm{v}$ aqueous solution of the carrier, respectively (Naveen, 2007).

\section{Dissolution kinetic modelling}

The in vitro drug release data was fitted to four models of data treatment for the complexes as follows:

Zero order: $F=k \times t$

First order: $\int F=k \times t$

Higuchi's model: $F=k \sqrt{t}$

Korsmeyer-Peppas model : $F=k t n$

Where $F$ is the fraction of drug release, $k$ is the release constant, $t$ is time and $\mathrm{n}$ is diffusional coefficient. The value of $n$ is related to the geometrical shape of the delivery system and determines the release mechanism from various polymeric drug deliveries (Jagdale et al., 2010). Kinetic modeling was done using PCP Disso software (version 3.0).

\section{Dissolution efficiency (DE) studies}

The drug release profiles was characterized by calculating the DE, which is defined as the area under the dissolution curve up to a certain time $t$, expressed as a percentage of the area of the rectangle arising from $100 \%$ 
dissolution at the same time. DE can be calculated by the following equation:

$$
D E=y\left(\frac{d t}{100 t}\right)
$$

where $y$ is the percent drug dissolved at time $t$. A convenient quantification of the effect of the carrier on drug dissolution may be obtained by considering $\log \mathrm{DE} / \mathrm{DE}_{\mathrm{NIF}}$, where $\mathrm{DE}$ and $\mathrm{DE}_{\mathrm{NIF}}$ are the dissolution efficiencies of the complex and the pure drug, respectively (Cutrignelli et al., 2008). DE was calculated using PCP Disso software (version 3.0).

\section{Similarity factor $\left(f_{2}\right)$}

The in vitro release profile of the pure drug was tested under similar conditions to those used for in vitro release testing of the test product. The similarity factor between the two samples (nifedipine and complexes) was determined using the data obtained from the drug release studies. The data were analyzed by the following formula.

$f_{2}=50 \log \left\{\left[1+(1 / n) \sum_{t=1}^{n} w_{t}\left(R_{t}-T_{t}\right)^{2}\right]^{-0.5}\right\} 100$

where, $\mathrm{n}$ is the number of withdrawal points, $\mathrm{R}_{\mathrm{t}}$ is the percentage reference dissolved at time point $t$, and $T_{t} i$ is the percentage test product dissolved at time point $t$. A value of $100 \%$ for $\mathrm{f}_{2}$ suggests that the test and reference profiles were identical. Values between 50 and 100 indicate that the dissolution profiles are similar while smaller values imply an increase in dissimilarity between the release profiles (Jagdale et al., 2009). Similarity factor was calculated using PCP Disso software (version 3.0).

\section{RESULTS AND DISCUSSIONS}

\section{Phase solubility analysis}

The phase solubility curve of nifedipine in the presence of $\beta-C D$ is shown in Figure 1. From this curve, it can be seen that the solubility of nifedipine increases due to the formation of an inclusion complex between nifedipine and $\beta$-CD. A linear increase in solubility of nifedipine was observed with an increase in concentration of $\beta-C D$ in water. The initial linear ascending part of the solubility diagram is generally ascribed to the formation of a 1:1 complex. The phase solubility plot showed an $\mathrm{A}_{\mathrm{L}}$ type solubility curve, which indicates that only $1: 1$ drug- $\beta-C D$ inclusion complex was formed in solution. The apparent stability constant $\left(\mathrm{K}_{1: 1}\right)$ for the nifedipine: $\beta$-CD complex was calculated from the solubility data and found to be $139.23 \mathrm{M}^{-1}$.

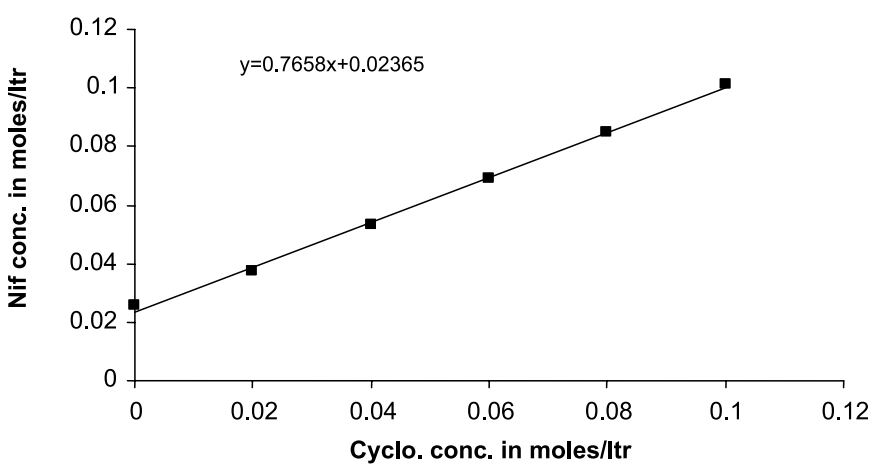

FIGURE 1- Phase solubility analysis plot for inclusion complexes.

An indication of the process of transfer of nifedipine from pure water to aqueous solution of $\beta-C D$ was obtained from the values of Gibbs free energy change. The values of Gibbs free energy obtained are shown in Table II. $\Delta \mathrm{G}_{\mathrm{tr}}^{\circ}$ values were all negative for $\beta-C D$ at various concentrations, indicating the spontaneous nature of nifedipine solubilization, and decreased with an increase in its concentration, demonstrating that the reaction became more favorable as the concentration of $\beta-\mathrm{CD}$ increased.

The negative nature of the Gibbs free energy changes $\left(\Delta \mathrm{G}_{\mathrm{tr}}{ }^{\circ}\right)(-5.099,-13.31,-21.30,-27.19,-31.84$ and -35.69 ) for $0.02,0.04$ and $0.06,0.08,0.1 \mathrm{moles} / \mathrm{ml}$ of water respectively) are indicative of the spontaneity of the process. The endothermic heats of solution further explain the increase in solubility with temperature.

TABLE II - Gibbs free energy of transfer $\left(\Delta \mathrm{G}_{\mathrm{tr}}^{\circ}\right)$ for solubilization process of nifedipine in aqueous solutions of $\beta-\mathrm{CD}$ at $37^{\circ} \mathrm{C}$.

\begin{tabular}{cc}
\hline Moles of $\beta$-CD in water & $\Delta \mathrm{G}_{\mathrm{tr}}{ }^{\circ}(\mathrm{KJ} / \mathrm{mol})$ \\
\hline 0 & -5.099 \\
0.02 & -13.31 \\
0.04 & -21.30 \\
0.06 & -27.19 \\
0.08 & 31.84 \\
0.1 & -35.69 \\
\hline
\end{tabular}

\section{Evaluation complexes}

\section{Drug content in drug: $\beta-C D(1: 1)$ complex}

Percentage drug content of the complexes are shown in Table III and found within the range 73 to $91 \%$. The maximum percent drug content was found to be $91.30 \%$ in the freeze-dried complex.

\section{Saturation solubility study}

The saturation solubility data for drug and com- 
TABLE III - Percentage drug content and saturation solubility of drug: $\beta-\mathrm{CD}(1: 1)$ complex

\begin{tabular}{lccc}
\hline Complexes & \% Drug Content & Solubility $(\boldsymbol{\mu g} \mathbf{m} \mathbf{m})$ & \% Increase in Solubility \\
\hline Drug & $\ldots \ldots \ldots \ldots \ldots \ldots$ \\
Physical mixture & 73.08 & 7.12 & $\ldots \ldots \ldots \ldots .$. \\
Kneading & 84.03 & 11.20 & $157.30 \%$ \\
Co-grounding & 89.56 & 21.60 & $303.37 \%$ \\
Co evaporation & 89.87 & 17.92 & $251.68 \%$ \\
Melting method & 87.23 & 21.15 & $297.05 \%$ \\
Freeze-Drying & 91.30 & 18.37 & $258.00 \%$ \\
Spray Drying & 90.56 & 28.15 & $395.36 \%$ \\
\hline
\end{tabular}

plexes are given in Table III. The freeze-dried complex shows maximum saturation solubility $(28.15 \mu \mathrm{g} / \mathrm{mL})$.

\section{Characterization of nifedipine: $\beta-C D(1: 1)$ complex}

\section{UV spectroscopic study}

The UV spectra of Nifedipine solution in the presence of $\beta-C D$ is shown in Figure 2 and Figure 3. There was no shift in the $\lambda_{\max }$ of Nifedipine in the presence of $\beta$-CD. The spectra of complexes showed a diminution in

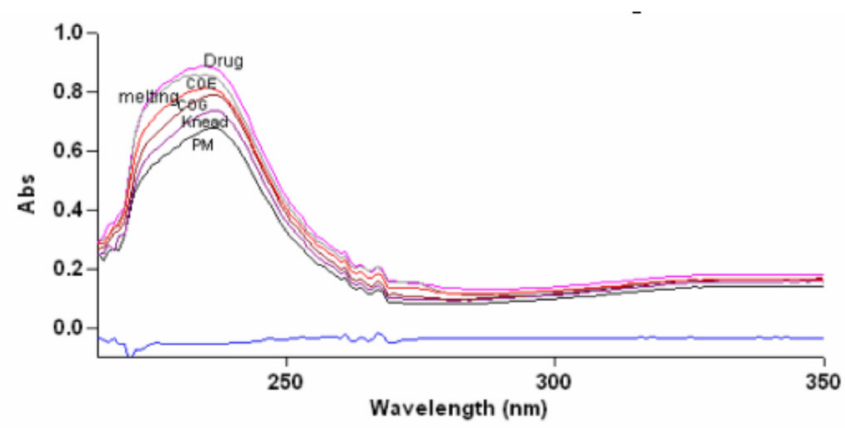

FIGURE 2 - Effect of $\beta$-CD concentration on UV absorption of nifedipine.

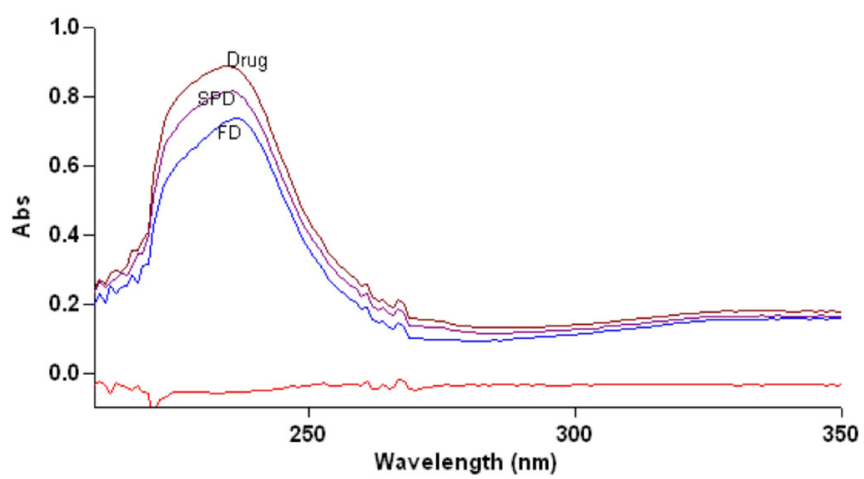

FIGURE 3 - Effect of $\beta$-CD concentration on UV absorption of nifedipine. absorbance at $238 \mathrm{~nm}$. The induced change in absorbance is attributed, primarily, to the formation of an inclusion complex. The changes in peak intensity are assumed to result from changes in the solvent microenvironment upon inclusion of the solute. The observed reduction in peak intensity may result from the transfer of the guest molecule from water to the $C D$ cavity.

FTIR

FTIR spectroscopy has been used to assess the interaction between drug and cyclodextrin molecules in the solid state. Figure 4 illustrates the FT-IR spectra of the samples under study. The chemical interaction between the drug and cyclodextrin often leads to identifiable changes in the infrared profile of dispersion. The drug spectrum shows prominent peaks at $3331 \mathrm{~cm}^{-1}, 3101 \mathrm{~cm}^{-1}$, $2931 \mathrm{~cm}^{-1}, 1689 \mathrm{~cm}^{-1}, 1624 \mathrm{~cm}^{-1}, 1528 \mathrm{~cm}^{-1}, 1380 \mathrm{~cm}^{-1}$, $1121 \mathrm{~cm}^{-1}$ corresponding to aromatic N-H stretching, $\mathrm{C}-\mathrm{H}$ aromatic stretching, $\mathrm{C}-\mathrm{H}$ aliphatic stretching, $\mathrm{C}=\mathrm{O}$ stretching in ester, $\mathrm{C}=\mathrm{C}$ aromatic, $-\mathrm{NO}_{2},-\mathrm{C}-\mathrm{CH}_{3}$ and $-\mathrm{C}$ $\mathrm{O}$-ester. The prominent peaks of $\beta-\mathrm{CD}$ are at $3326 \mathrm{~cm}^{-1}$, $2950 \mathrm{~cm}^{-1}, 1200 \mathrm{~cm}^{-1}$ and $1000 \mathrm{~cm}^{-1}$ corresponding to $\mathrm{C}-\mathrm{H}$ stretching, C-H stretching, C-C-O asymmetric stretching and $\mathrm{OH}$ bending, respectively. It was noted that the ester carbonyl stretching bend of nifedipine shifted from 1689 down to a lower $1675 \mathrm{~cm}^{-1}$ where this might be attributed to intermolecular hydrogen bonding between nifedipine and $\beta-C D$. Moreover, the absorption band at $3331 \mathrm{~cm}^{-1}$ ascribed to stretching vibration of the N-H bond in the dihydropyridine ring was broadened, slightly shifted or nearly disappeared in inclusion complex spectra. Thus, IR spectra indicate that the nifedipine molecule is included in the $\beta$-CD cavity through the dihydropyridine ring. The physical mixture of drug with $\beta$-CD (1:1) and drug: $\beta$-CD complexes show the prominent peaks of drug, but there was a reduction in peak intensity of drug peaks which was obscured by the cyclodextrin peak indicating formation of complexes. 


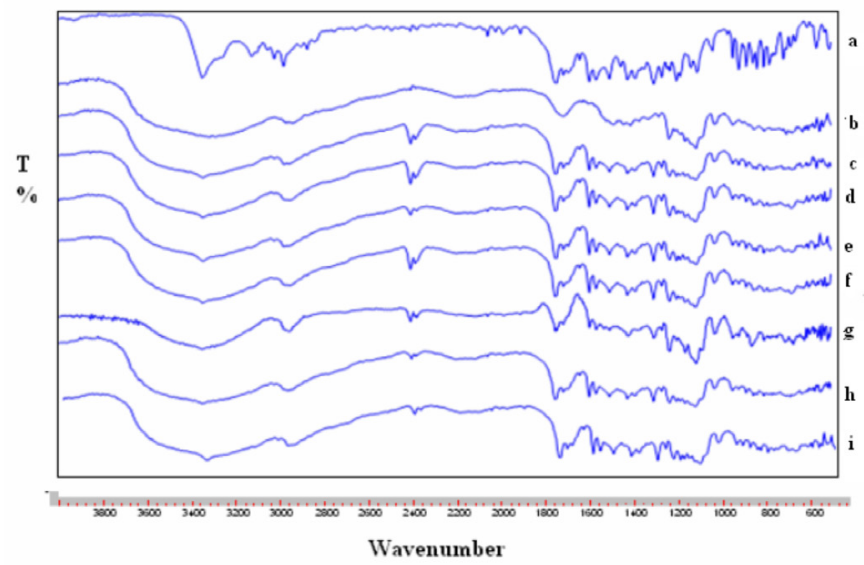

FIGURE 4 - IR spectral analysis of drug (a), $\beta$-CD (b), physical mixture (c) kneading method (d), coevaporation method (e), co-grounding (f), spray drying( g), melting method (h), freeze drying (i).

\section{$X$-ray diffractometry [XRD]}

Powder X-ray diffraction spectroscopy has been used to assess the degree of crystallinity of the given sample. When complexation of drug and $\beta-C D$ are formed, the overall number of crystalline structures is reduced and the number of amorphous structures is increased. Thus, the final product sample shows fewer, less intense peaks. This shows that overall crystallinity of complexes is decreased and due to a more amorphous nature, solubility is increased. XRD patterns are shown in Figure 5. The powder X-ray diffractogram of pure nifedipine showed

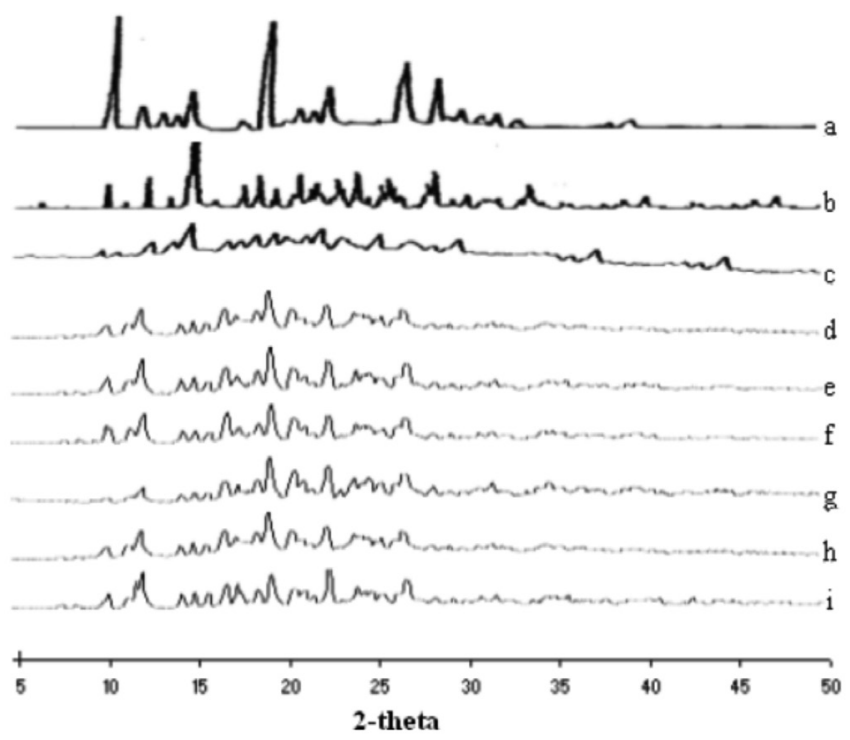

FIGURE 5 - X-Ray Diffraction of pure nifedipine (a); pure $\beta$-CD (b); physical mixture (c); coevaporation complex (d); kneading complex (e); cogrounding complex (f); freeze drying complex (g); spray drying complex (h); melting complex (i). numerous distinctive peaks that indicated a high crystallinity. $\beta$-CD exhibited characteristic peaks at $10.62,12.46$, $15.42,16.98,20.94,22.80$ due to its crystalline nature. The diffractograms of complexes were found to be more diffuse compared to drug, while there is no characteristic peak i.e. formation of amorphous solid state (inclusion complex formation).

DSC

DSC enables the quantitative detection of all processes in which energy is required or produced (i.e., endothermic or exothermic phase transformations). Thermograms for drug and complexes are shown in Figure 6. DSC studies showed that endothermic peaks for pure nifedipine and $\beta-\mathrm{CD}$ were obtained at $175.1^{\circ} \mathrm{C}$ and $85.11^{\circ} \mathrm{C}$, respectively. The thermogram of drug: $\beta-\mathrm{CD}$ (1:1) complex showed complete disappearance of the peak of nifedipine and a shift in the endothermic peak of $\beta-C D$. These findings indicate successful complexation with $\beta$-CD. Thus, DSC studies confirmed the inclusion complexation of drug with $\beta-\mathrm{CD}$.
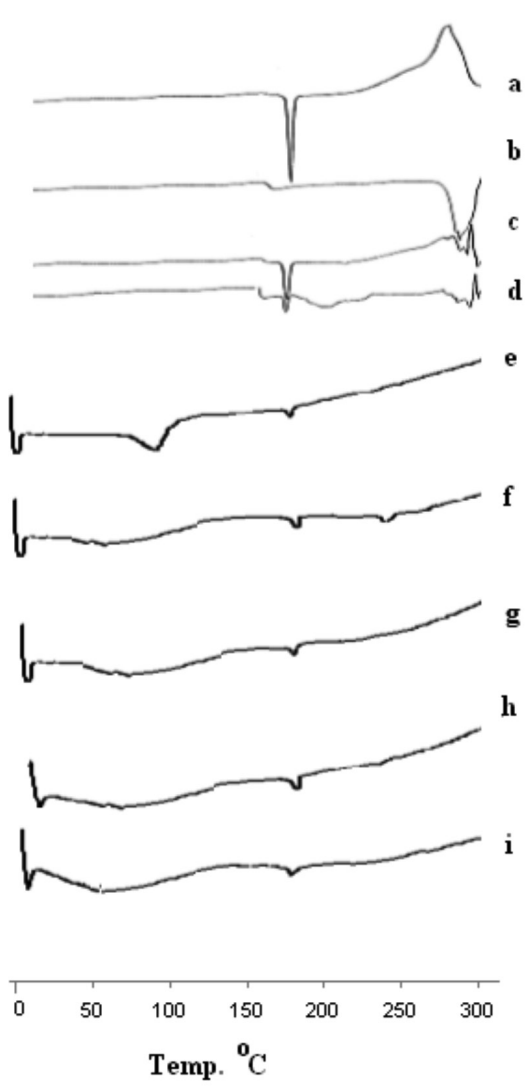

FIGURE 6 - DSC study of pure nifedipine(a); pure $\beta$-CD (b); physical mixture (c); coevaporation complex (d); kneading complex (e); cogrounding complex (f); freeze drying complex (g); spray drying complex (h); melting complex (i). 


\section{In vitro release profile of complexes}

Dissolution profiles of pure nifedipine and complexes are shown in Figure 7 and Figure 8. It is evident that the complexation technique has improved the dissolution rate of nifedipine to a great extent. From in vitro release study (Figure 7 and Figure 8), it was found that the complex prepared as $1: 1$ by the freeze-drying method showed an improvement in dissolution behavior compared to drug and other complexes. This might be due to the inclusion complex formation, indicating the improved solubility phenomenon.

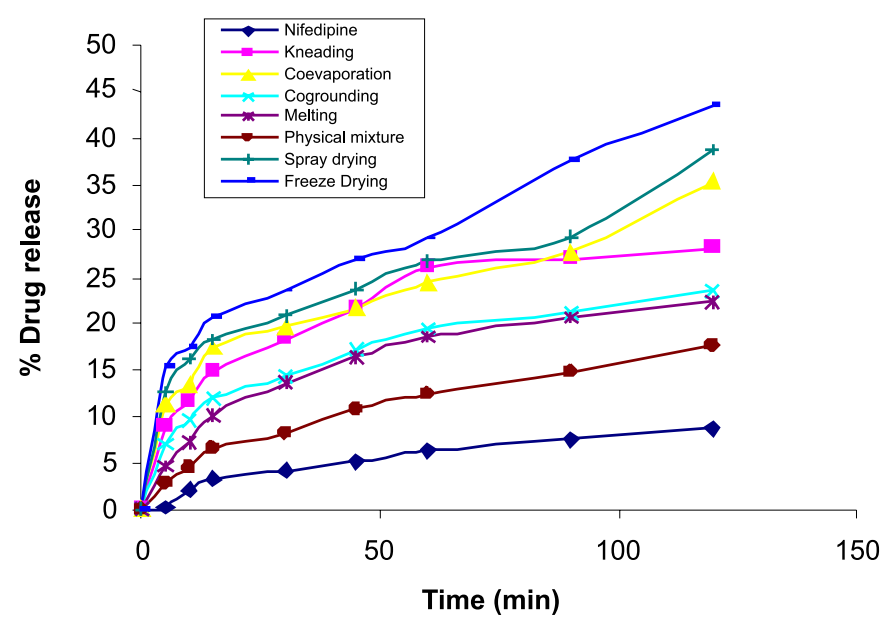

FIGURE 7 - \% Drug release of drug and its complexes in Distilled Water.

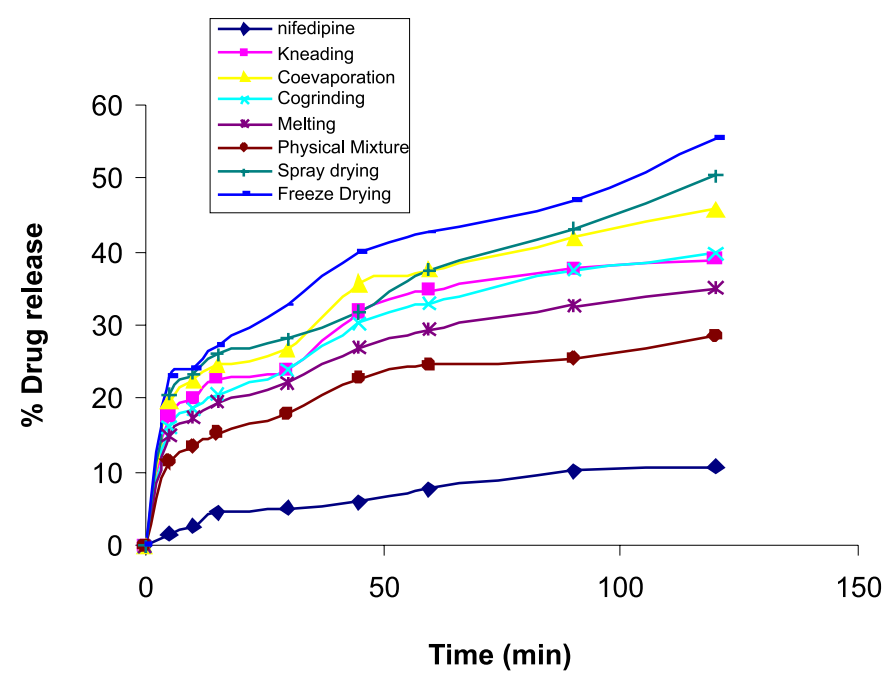

FIGURE 8 - \% Drug release of drug and its complexes in Phosphate buffer at $\mathrm{pH} 6.8$.

\section{Dissolution kinetic modeling}

To interpret the release kinetics and mechanism of drug release from complexes, the coefficient of determina- tion was considered as the main parameter for interpreting the results. The $\mathrm{n}$ values of all formulations are as reported in Table IV and Table V. None of the formulations of complexes fit a specific model.

The value of ' $n$ ' gives an indication of the release mechanism; when $n=1$, the release rate is independent of time (zero-order) (case II transport), $n=0.5$ for Fickian diffusion and when $0.5<n<1.0$, diffusion and non-Fickian transport are implicated. Lastly, when $n>1.0$ super case II transport is apparent (Korsemeyer et al., 1983).

$\mathrm{DP}_{60}$ indicates \% drug dissolved in 60 minutes, $\mathrm{DP}_{120}$ $\%$ drug dissolved in 120 minutes and $\mathrm{DE}_{60}$ indicates dissolution efficiency at 60 minutes for nifedipine and its binary systems with carriers in distilled water/phosphate buffer. $\mathrm{T}_{50 \%}$ indicates the time required for $50 \%$ release of drug.

The release kinetic analyses of all formulations in distilled water are as shown in Table IV. The $\mathrm{n}$ value for all the formulation was found to be below 0.5 (0.2965 to 0.4814 ) thus the release was predominantly by diffusion and a non-Fickian transport mechanism. The freeze-dried complex showed an $n$ value of 0.3050 indicating diffusion as the predominant mechanism of drug release. Freeze-dried complex $\left(\mathrm{DE}_{60}=24.17 \%\right)$ produced the maximum enhancement in dissolution rate. The $\mathrm{f}_{2}$ value of similarity factor indicate that the co-grinding method and melting method proved similar to the release mechanism of the pure drug, with a value greater than 50 . For all other formulations, the value of the similarity factor was less than 50 , thus dissimilar in the release mechanism of drug whereas the dissolution profile of the drug was better than that of pure nifedipine. Regression analysis was performed and regression values ' $\mathrm{R}^{2}$ ' were 0.9815 to 0.9977 for different formulations.

The release kinetic analyses of all formulations in phosphate buffer are as shown in Table IV. The $n$ value for all the formulations was found to be below $0.5(0.2591$ to 0.4233 ) thus the release was predominantly by diffusion and a non-Fickian transport mechanism. The freezedried complex showed an $n$ value of 0.2793 indicating diffusion as the predominant mechanism of drug release. Freeze-dried complex $\left(\mathrm{DE}_{60}=33.76 \%\right)$ showed the maximum enhancement in dissolution rate. The $f_{2}$ value of all formulations was less than 50, thus dissimilar in release mechanism of drug whereas the dissolution profile of the drug was better than that of pure Nifedipine. Regression analysis was performed and regression values ' $\mathrm{R}^{2}$ ' were 0.9716 to 0.9939 for different formulations.

\section{Evaluation of fast-dissolving tablets}

To formulate a fast-dissolving tablet of nifedipine, the freeze dried complex was selected based on 
TABLE IV - Dissolution parameter of complexes in distilled water

\begin{tabular}{|c|c|c|c|c|c|c|c|c|c|}
\hline \multirow{2}{*}{ Complexes } & \multicolumn{2}{|c|}{ DP } & \multirow{2}{*}{$\mathrm{T}_{50 \%}$} & \multicolumn{2}{|c|}{$\% \mathrm{DE}$} & \multirow{2}{*}{$\begin{array}{l}\text { Best Fit } \\
\text { mode }\end{array}$} & \multirow{2}{*}{$\mathrm{N}$} & \multirow{2}{*}{$\mathrm{R}^{2}$} & \multirow{2}{*}{$\mathrm{f}_{2}$} \\
\hline & $\mathrm{DP}_{60}$ & $\mathrm{DP}_{120}$ & & $\mathrm{DE}_{60}$ & $\mathrm{DE}_{120}$ & & & & \\
\hline Nifedipine & 6.27 & 8.6940 & 478.46 & 5.55 & 7.46 & Matrix & 0.4814 & 0.9897 & ------ \\
\hline $\mathrm{Kn}$ & 25.95059 & 28.0956 & 115.60 & 19.12 & 24.11 & Peppas & 0.3460 & 0.9924 & 41.60 \\
\hline $\mathrm{COE}$ & 24.52767 & 35.25296 & 122.34 & 20.07 & 25.49 & Peppas & 0.3104 & 0.9855 & 39.12 \\
\hline $\mathrm{COG}$ & 19.56166 & 23.41779 & 153.37 & 15.42 & 19.39 & Peppas & 0.3387 & 0.9960 & 48.54 \\
\hline Melt & 18.53715 & 22.283 & 161.89 & 10.84 & 14.62 & Matrix & 0.4177 & 0.9944 & 50.91 \\
\hline PM & 12.48972 & 17.58024 & 240.38 & 9.65 & 13.23 & Matrix & 0.4590 & 0.9977 & 63.90 \\
\hline FD & 29.09881 & 43.36364 & 103.12 & 24.17 & 31.64 & Peppas & 0.3050 & 0.9815 & 32.98 \\
\hline SPD & 26.67273 & 38.81028 & 112.48 & 21.74 & 27.49 & Peppas & 0.2965 & 0.9830 & 36.67 \\
\hline
\end{tabular}

TABLE V - Dissolution parameter of complexes in phosphate buffer

\begin{tabular}{|c|c|c|c|c|c|c|c|c|c|}
\hline \multirow{2}{*}{ Complexes } & \multicolumn{2}{|c|}{ DP } & \multirow{2}{*}{$\mathrm{T}_{50 \%}$} & \multicolumn{2}{|c|}{$\% \mathrm{DE}$} & \multirow{2}{*}{$\begin{array}{l}\text { Best Fit } \\
\text { mode }\end{array}$} & \multirow{2}{*}{$\mathrm{n}$} & \multirow{2}{*}{$\mathrm{R}^{2}$} & \multirow{2}{*}{$\mathrm{f}_{2}$} \\
\hline & $\mathrm{DP}_{60}$ & $\mathrm{DP}_{120}$ & & $\mathrm{DE}_{60}$ & $\mathrm{DE}_{120}$ & & & & \\
\hline$\overline{\text { Nif }}$ & 7.7549 & 10.828 & 387.09 & 6.48 & 9.04 & Matrix & 0.4233 & 0.9898 & - \\
\hline $\mathrm{Kn}$ & 34.86166 & 39.02372 & 86.05 & 27.01 & 33.31 & Peppas & 0.2591 & 0.9827 & 33.01 \\
\hline $\mathrm{COE}$ & 37.63636 & 45.78261 & 79.72 & 27.01 & 33.32 & Peppas & 0.2591 & 0.9827 & 29.94 \\
\hline $\mathrm{COG}$ & 33.083 & 39.77075 & 90.68 & 25.85 & 32.49 & Peppas & 0.2869 & 0.9920 & 33.83 \\
\hline MELT & 29.49012 & 35.14625 & 101.72 & 23.68 & 29.19 & Peppas & 0.2668 & 0.9951 & 36.95 \\
\hline $\mathrm{PM}$ & 24.51344 & 28.63636 & 122.39 & 19.57 & 23.88 & Peppas & 0.2811 & 0.9939 & 43.40 \\
\hline FD & 42.68775 & 55.38735 & 70.29 & 33.76 & 42.08 & Peppas & 0.2793 & 0.9842 & 26.18 \\
\hline SPD & 50.40711 & 37.63636 & 59.52 & 29.45 & 37.71 & Peppas & 0.2626 & 0.9716 & 29.17 \\
\hline
\end{tabular}

its saturation solubility and in-vitro dissolution performance. Three different superdisintegrants, dosion (DO), crospovidone(CRP), and croscarmellose sodium (CCS) with different concentrations $(6 \%, 8 \%, 10 \%)$ were tried in order to achieve fast dispersion of tablets.

Micromeritic properties of tablet powder were calculated and tabulated in Table VI. Bulk Density, tapped density, Carr's index and Hausner Ratio were found to be $0.6774 \mathrm{gm} / \mathrm{cm}^{3} \pm 0.0170,0.8111 \mathrm{gm} / \mathrm{cm}^{3} \pm 0.0324,16.41$ $\% \pm 2.20$, and $1.1971 \pm 0.0313$, respectively. Hausner Ratio was found to be less than 1.25 , evidencing good flow. Carr's index was in the 12.82-18.91 range; hence was fair to passable.

All the formulations exhibited a yellow color, were odorless, flat circular in shape and had a smooth surface. The prepared tablets were evaluated for hardness, friability, weight variation, thickness, in vitro disintegration time, water absorption ratio and \% assay, with data shown in Table VII. Hardness and friability of all formulations were within acceptable limits. Hardness of tablets prepared by direct compression was $3.19-3.63 \mathrm{~kg} / \mathrm{cm}^{2}$. The friability of all formulations was found to be less than $1.0 \%$ and hence the tablets with lower friability do not break during handling on machines and or shipping. The average weight of the fast-dissolving tablets prepared by the direct compression method was $257-259 \mathrm{mg}$. Thickness of tablet was found to lie within the range $3.16 \pm 0.40 \mathrm{~mm}$.

The $\%$ drug content of the prepared tablets was in the range 97.01 to $98.55 \%$ per tablet. Low values of standard $(0.15 \%-0.61 \%)$ deviation in terms of drug content indicate uniform drug distribution and application of all methods for the preparation of complexes with high content uniformity.

Disintegration time is very important for fast-dissolving tablet with a desired value of less than 3 min (Korsemeyer et al., 1983). Disintegration time of the prepared fast-dissolving tablet was in the range 0.51 to $3.5 \mathrm{~min}$.

Figure 9 and Figure10 show that the formulations DO II, CRP II and CCS II exhibited maximum release in distilled water and in phosphate buffer at $\mathrm{pH} 6.8$ compared to other formulations. Hence, these three formulations were selected for stability study. 
TABLE VI - Physical characterization of nifedipine blend

\begin{tabular}{|c|c|c|c|c|}
\hline Formulation & $\begin{array}{l}\text { Bulk Density } \\
\left(\mathrm{gm} / \mathrm{cm}^{3}\right)\end{array}$ & $\begin{array}{c}\text { Tapped Density } \\
\left(\mathrm{gm} / \mathrm{cm}^{3}\right)\end{array}$ & $\begin{array}{c}\text { Carr's Index } \\
(\%)\end{array}$ & $\begin{array}{c}\text { Hausner } \\
\text { Ratio }\end{array}$ \\
\hline Control & 0.6666 & 0.7640 & 12.820 & 1.1470 \\
\hline DO I & 0.6666 & 0.7878 & 15.384 & 1.1818 \\
\hline DO II & 0.6842 & 0.8125 & 15.789 & 1.1875 \\
\hline DO III & 0.6666 & 0.8125 & 17.948 & 1.2187 \\
\hline PGS I & 0.6842 & 0.8387 & 18.421 & 1.2258 \\
\hline PGS II & 0.6842 & 0.8387 & 18.421 & 1.2258 \\
\hline PGS III & 0.6666 & 0.8125 & 17.948 & 1.2187 \\
\hline CRP I & 0.7027 & 0.8125 & 13.513 & 1.1562 \\
\hline CRP II & 0.6842 & 0.8387 & 18.421 & 1.2258 \\
\hline CRP III & 0.7027 & 0.8666 & 18.918 & 1.2333 \\
\hline SSG I & 0.6666 & 0.8125 & 17.948 & 1.2187 \\
\hline SSG II & 0.6842 & 0.8387 & 18.421 & 1.2258 \\
\hline SSG III & 0.7647 & 0.8965 & 14.705 & 1.1724 \\
\hline CCS I & 0.6842 & 0.8387 & 18.4210 & 1.2258 \\
\hline CCS II & 0.6666 & 0.8125 & 17.9487 & 1.2187 \\
\hline CCS III & 0.65 & 0.7647 & 15 & 1.1764 \\
\hline
\end{tabular}

TABLE VII - Evaluation of fast-dissolving tablets

\begin{tabular}{lccccccc}
\hline Formulation & $\begin{array}{c}\text { Hardness** } \\
\left(\mathrm{kg} / \mathrm{cm}^{2}\right)\end{array}$ & $\begin{array}{c}\text { Friability } \\
(\%)\end{array}$ & $\begin{array}{c}\text { Thickness** } \\
(\mathrm{mm})\end{array}$ & $\begin{array}{c}\text { D.T } \\
(\mathrm{min}) * *\end{array}$ & $\begin{array}{c}\text { Average weight } \\
(\mathrm{mg}) *\end{array}$ & $\begin{array}{c}\text { Water } \\
\text { absorption ratio }\end{array}$ & \% Assay \\
\hline Control & $3.19 \pm 0.07$ & 0.70 & $3.16 \pm 0.40$ & $3.5 \pm 0.127$ & $257 \pm 0.63$ & $168.4 \pm 0.1$ & $97.3 \pm 0.23$ \\
DO I & $3.22 \pm 0.14$ & 0.76 & $3.02 \pm 0.01$ & $1.55 \pm 0.04$ & $257.83 \pm 0.98$ & $135.4 \pm 0.9$ & $98.28 \pm 0.25$ \\
DO II & $3.23 \pm 0.11$ & 0.63 & $3.33 \pm 0.51$ & $1.12 \pm 0.02$ & $257 \pm 0.6324$ & $124.1 \pm 0.2$ & $98.5 \pm 0.43$ \\
DO III & $3.19 \pm 0.07$ & 0.72 & $3.5 \pm 0.54$ & $1.25 \pm 0.03$ & $257.66 \pm 0.81$ & $138.0 \pm 1.6$ & $97.2 \pm 0.55$ \\
PGS I & $2.9 \pm 1.31$ & 0.76 & $3.3 \pm 0.02$ & $3.2 \pm 0.012$ & $255.6 \pm 0.529$ & $135.4 \pm 0.9$ & $98.28 \pm 0.25$ \\
PGS II & $3.2 \pm 1.06$ & 0.63 & $3.4 \pm 0.04$ & $3.10 \pm 0.04$ & $255.2 \pm 1.058$ & $95.0 \pm 1.21$ & $98.07 \pm 0.61$ \\
PGS III & $3.4 \pm 0.89$ & 0.72 & $3.1 \pm 0.02$ & $2.15 \pm 0.05$ & $256.83 \pm 0.59$ & $148.6 \pm 0.4$ & $97.45 \pm 0.17$ \\
CRP I & $3.3 \pm 0.032$ & 0.78 & $3.3 \pm 0.05$ & $1.60 \pm 0.57$ & $258.06 \pm 0.70$ & $152.0 \pm 0.6$ & $98.59 \pm 0.29$ \\
CRP II & $3.20 \pm 0.10$ & 0.79 & $3.2 \pm 0.53$ & $0.51 \pm 0.07$ & $258.93 \pm 0.90$ & $90.4 \pm 0.84$ & $97.01 \pm 0.15$ \\
CRP III & $3.63 \pm 0.15$ & 0.62 & $3.2 \pm 0.22$ & $0.72 \pm 0.57$ & $259.33 \pm 0.57$ & $98.2 \pm 0.12$ & $97.12 \pm 0.43$ \\
SSG I & $3.62 \pm 0.15$ & 0.75 & $3.1 \pm 0.02$ & $3.34 \pm 0.03$ & $257.16 \pm 1.04$ & $90.4 \pm 0.84$ & $97.01 \pm 0.15$ \\
SSG II & $3.53 \pm 0.15$ & 0.82 & $3.02 \pm 0.01$ & $2.4 \pm 0.026$ & $256.83 \pm 0.76$ & $98.2 \pm 0.12$ & $97.12 \pm 0.43$ \\
SSG III & $3.2 \pm 0.100$ & 0.85 & $3.02 \pm 0.02$ & $2 \pm 0.05$ & $255.5 \pm 0.500$ & $122.4 \pm 0.2$ & $98.15 \pm 0.21$ \\
CCS I & $3.23 \pm 0.15$ & 0.78 & $3.1 \pm 0.02$ & $2.15 \pm 0.01$ & $257.66 \pm 0.57$ & $122.4 \pm 0.2$ & $98.15 \pm 0.21$ \\
CCS II & $3.36 \pm 0.05$ & 0.64 & $3.02 \pm 0.01$ & $1.30 \pm 0.57$ & $259.70 \pm 0.35$ & $95.0 \pm 1.21$ & $98.07 \pm 0.61$ \\
CCS III & $3.46 \pm 0.01$ & 0.68 & $3.02 \pm 0.02$ & $1.45 \pm 0.02$ & $258.43 \pm 0.52$ & $148.6 \pm 0.4$ & $97.45 \pm 0.17$ \\
\hline
\end{tabular}

$*$ average $\pm \mathrm{sd}, \mathrm{n}=20, * *$ average $\pm \mathrm{sd}, \mathrm{n}=6$.

Figure 11 shows the effect of superdisintegrant on D.T. Doshion is ion exchange resins. Doshion shows a decrease in D.T. as concentration increases. Hence 8\% Doshion was selected. Crospovidone shows a decrease in D.T. as concentration increases. This was because CRP exhibits a capillary mechanism of disintegration. When in contact with water it replaces the air absorbed by par- ticles. This weakens the intermolecular bond and breaks the tablet into smaller particles. As the concentration of CRP increased, the number of capillaries also increased thus increasing the channeling of water. Therefore, the rate of liberation to primary particles increases. Hence, $8 \%$ CRP was selected. CCS showed a decrease in D.T. as concentration increases. Hence, $8 \%$ CCS was selected. 


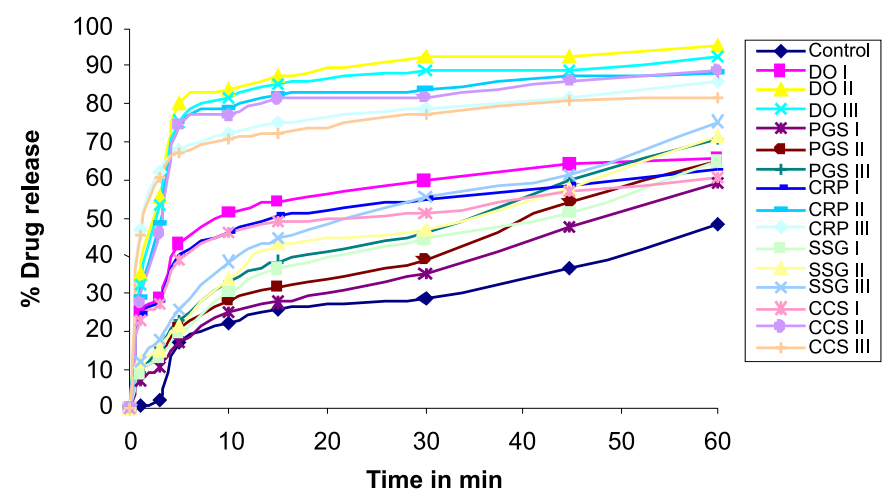

FIGURE 9 - \% Drug release from tablet in Phosphate buffer at pH 6.8 .

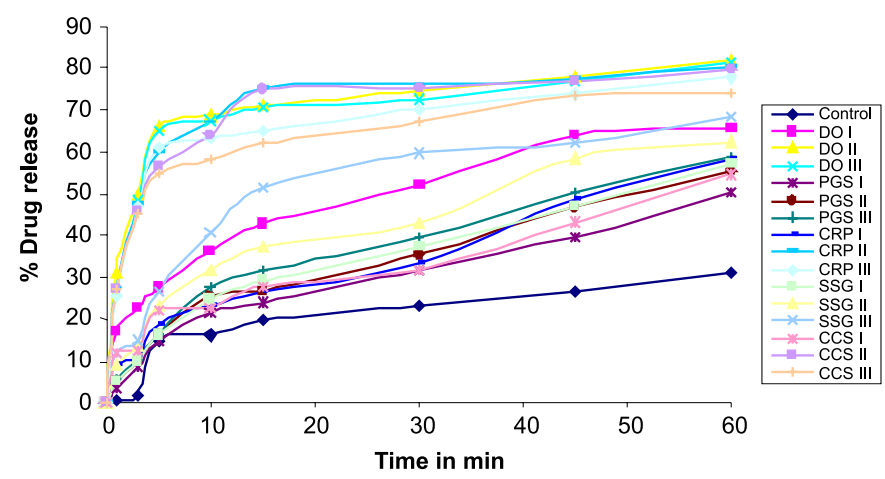

FIGURE 10 - \% Drug release from tablet in Distilled water.

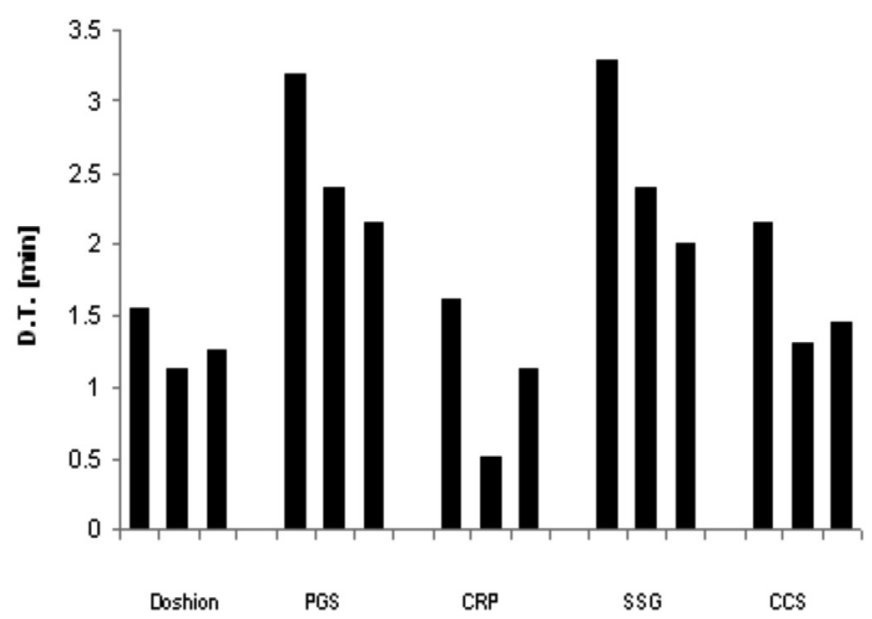

Effect of superdisintegrants

FIGURE 11- Effect of concentration of superdisintegrants.

\section{Stability testing}

From the stability data in Table VIII and Table IX for batches DO II, CRP II and CCS III, it can be concluded that there were no significant changes in any parameters, and optimized batches i.e. DO II, CRP II and CCS II are therefore deemed stable. Hence, this product can be kept for a period of one year or more.

TABLE VIII - Stability testing - i) $30 \pm 1{ }^{\circ} \mathrm{C}$ and RH $65 \% \pm 5 \%$

\begin{tabular}{|c|c|c|c|c|c|c|c|}
\hline Formulation & Parameter & Initial & $\begin{array}{c}30{ }^{\circ} \mathrm{C} / 65 \% \mathrm{RH} \\
7 \text { days }\end{array}$ & $\begin{array}{c}30{ }^{\circ} \mathrm{C} / 65 \% \mathrm{RH} \\
14 \text { days }\end{array}$ & $\begin{array}{c}30{ }^{\circ} \mathrm{C} / 65 \% \mathrm{RH} \\
1 \text { Month }\end{array}$ & $\begin{array}{c}30^{\circ} \mathrm{C} / 65 \% \mathrm{RH} \\
2 \text { Months }\end{array}$ & $\begin{array}{c}30^{\circ} \mathrm{C} / 65 \% \mathrm{RH} \\
3 \text { Months }\end{array}$ \\
\hline \multirow[t]{3}{*}{ DO II } & Hardness $* *\left(\mathrm{~kg} / \mathrm{cm}^{2}\right)$ & $3.23 \pm 0.11$ & $3.2 \pm 0.19$ & $3.3 \pm 0.57$ & $3.13 \pm 0.51$ & $3.15 \pm 0.47$ & $3.1 \pm 0.19$ \\
\hline & Thickness** (mm) & $3.33 \pm 0.51$ & $3 \pm 0.02$ & $3.3 \pm 0.22$ & $3.3 \pm 0.03$ & $3.1 \pm 0.04$ & $3.3 \pm 0.02$ \\
\hline & D.T $(\min ) * *$ & $1.12 \pm 0.05$ & $1.12 \pm 0.07$ & $1.15 \pm 0.3$ & $1.15 \pm 0.4$ & $1.16 \pm 0.20$ & $1.14 \pm 0.5$ \\
\hline \multirow[t]{4}{*}{ CRP II } & Hardness $* *\left(\mathrm{~kg} / \mathrm{cm}^{2}\right)$ & $3.20 \pm 0.10$ & $3.36 \pm 0.08$ & $3.32 \pm 0.05$ & $3.27 \pm 0.05$ & $3.44 \pm 0.19$ & $3.11 \pm 0.072$ \\
\hline & Friability (\%) & 0.79 & 0.74 & 0.65 & 0.68 & 0.72 & 0.65 \\
\hline & Thickness** (mm) & $3.2 \pm 0.53$ & $3.21 \pm 0.02$ & $3.43 \pm 0.05$ & $3.12 \pm 0.01$ & $3.14 \pm 0.02$ & $3.15 \pm 0.06$ \\
\hline & D.T. $(\min ) * *$ & $0.51 \pm 0.07$ & $0.55 \pm 0.02$ & $0.54 \pm 0.08$ & $0.50 \pm 0.09$ & $0.58 \pm 0.01$ & $0.53 \pm 0.02$ \\
\hline \multirow{5}{*}{ CCS II } & Friability $(\%)$ & 0.64 & 0.70 & 0.68 & 0.65 & 0.69 & 0.70 \\
\hline & Thickness** $(\mathrm{mm})$ & $3.02 \pm 0.01$ & $3.1 \pm 0.03$ & $3.2 \pm 0.100$ & $3.03 \pm 0.057$ & $3.1 \pm 0.10$ & $3.3 \pm 0.04$ \\
\hline & D.T $(\min ) * *$ & $1.30 \pm 0.577$ & $1.35 \pm 0.026$ & $1.36 \pm 0.01$ & $1.38 \pm 0.015$ & $1.38 \pm 0.025$ & $1.40 \pm 0.014$ \\
\hline & Assay \% & $98.07 \pm 0.61$ & $97.21 \pm 0.15$ & $98.89 \pm 0.41$ & $97.37 \pm 0.24$ & $97.45 \pm 0.52$ & $98.89 \pm 0.15$ \\
\hline & Average weight $(\mathrm{mg}) *$ & $259.70 \pm 0.35$ & $257.16 \pm 0.24$ & $258 \pm 1.00$ & $258 \pm 1.50$ & $257.18 \pm 1.23$ & $258 \pm 1.12$ \\
\hline
\end{tabular}

$*$ average $\pm \mathrm{sd}, \mathrm{n}=10$, ** average $\pm \mathrm{sd}, \mathrm{n}=6$. 
TABLE IX - Stability testing - ii) $40 \pm 2{ }^{\circ} \mathrm{C}$ and RH $75 \% \pm 5 \%$

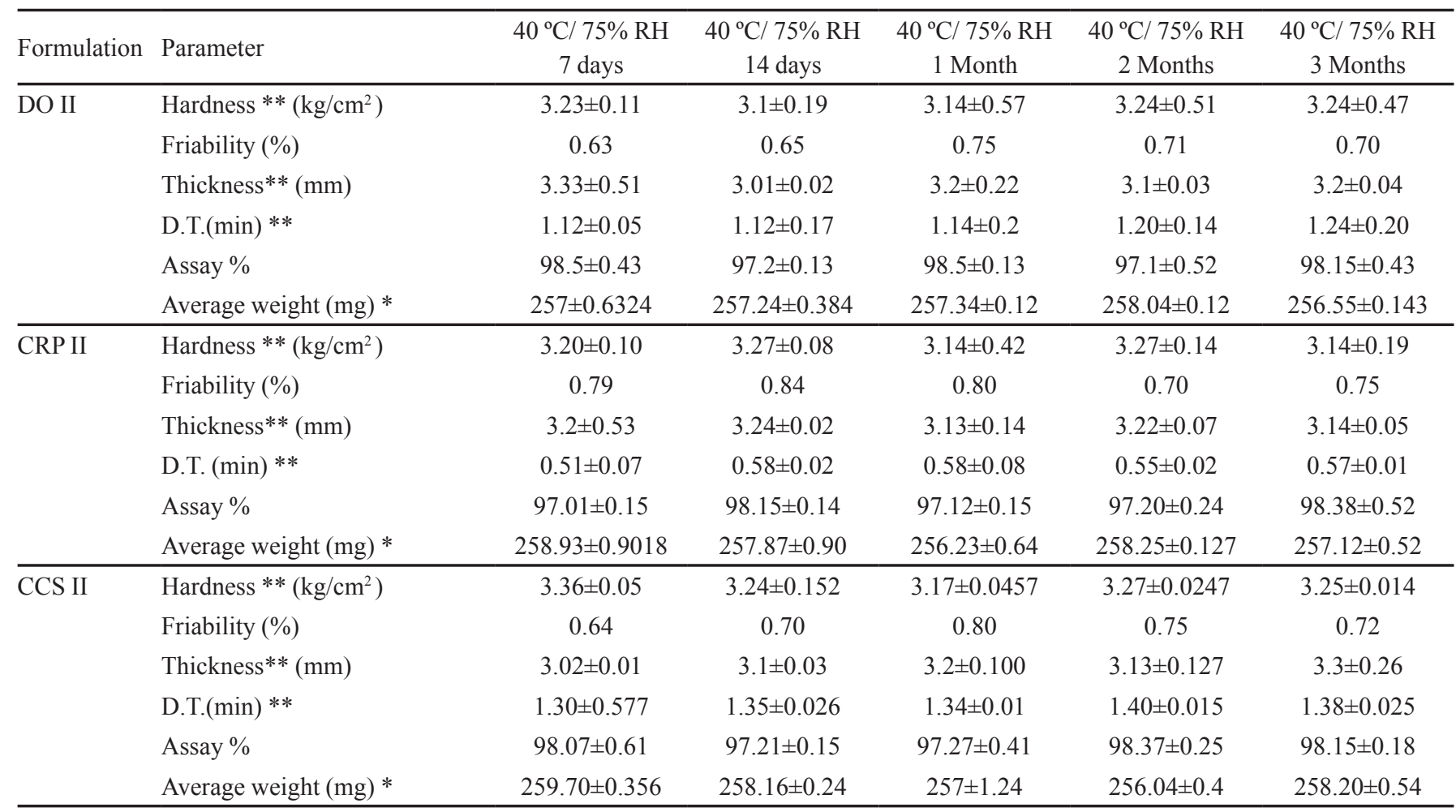

$*$ average $\pm \mathrm{sd}, \mathrm{n}=10, * *$ average $\pm \mathrm{sd}, \mathrm{n}=6$.

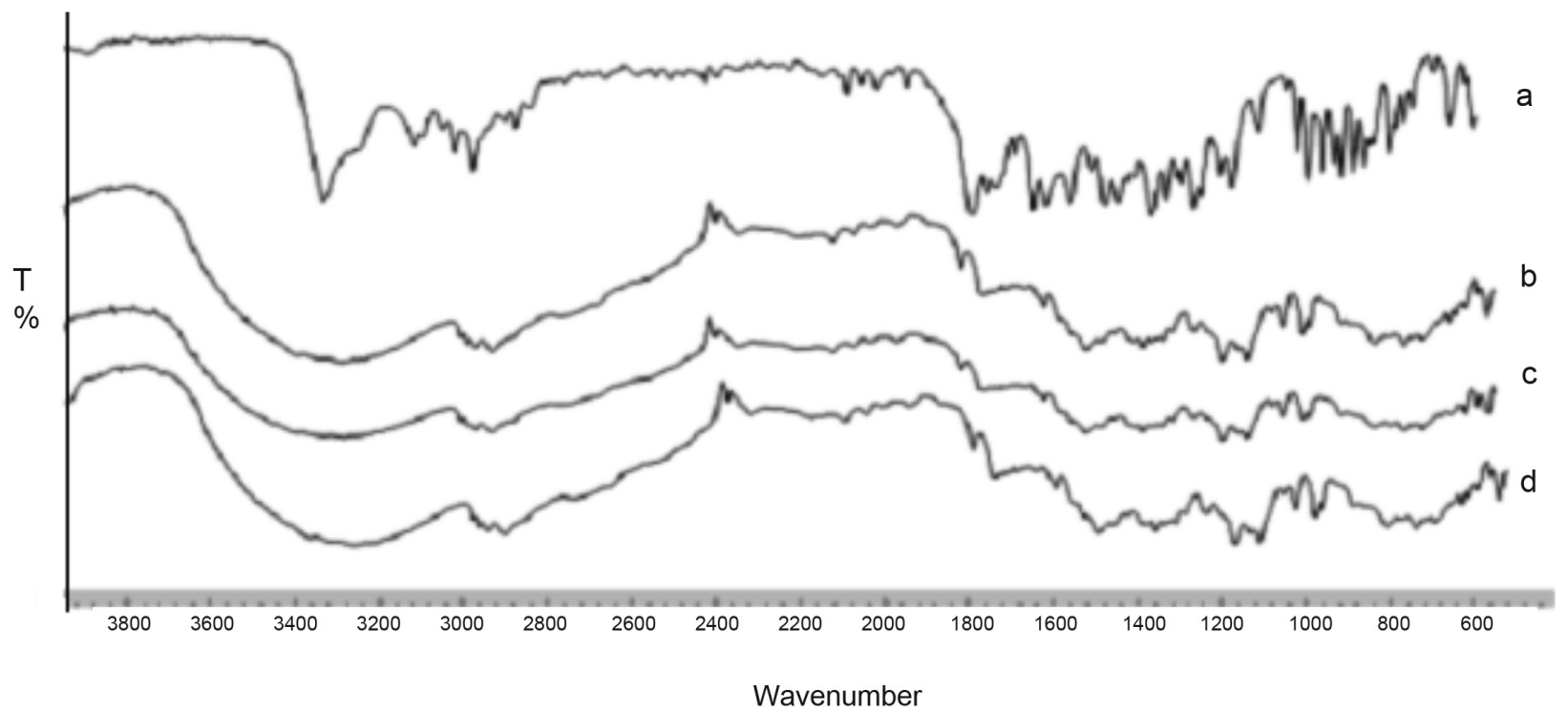

FIGURE 12 - I.R of Nifedipine (a), DO II (b), CRP II (c) and CCS II (d).

\section{Infrared Spectroscopy Study of Tablet}

From the above spectrum (Figure 12), it can be seen that the major peaks of the drug were unchanged, i.e. there was no interaction between drug and excipients for DO II, CRP II or CCS II.

\section{CONCLUSION}

The dissolution rate of nifedipine was successfully enhanced by the cyclodextrin complexation technique. The method of preparing complexes played a key role in enhancing the dissolution rate. The enhancement of the 
dissolution rate helped toward providing rapid onset of action of the drug. Fast-dissolving tablet also helped toward the enhancement of dissolution rate.

Based on the findings of various tests it can be concluded that,

1. Inclusion complexes significantly improved dissolution profiles.

2. Inclusion complexes of nifedipine produced by different methods exhibited the following order of enhanced solubility: freeze-drying $>$ spray drying $>$ kneading $>$ coevaporation $>$ melting $>$ co-grounding $>$ physical mixture.

3. X-Ray diffraction, differential scanning calorimetric data and IR and UV spectral analysis results indicated no probable interaction between drug and $\beta-C D$.

4. The inclusion complexes with cyclodextrin prepared by the freeze-drying method showed highest solubility $(28.15 \mu \mathrm{g} / \mathrm{ml})$ and a fast dissolution profile.

5. These investigations demonstrated that it is possible to prepare fast-dissolving tablets by a direct compression method.

6. Disintegration time decreased with increased concentration of superdisintegrants. Formulations of doshion ( $8 \%$ ), crospovidone (8\%) and croscarmellose sodium ( $8 \%$ ) showed faster disintegration and maximum percent of drug release.

\section{ACKNOWLEDGEMENT}

The authors are grateful to the University of Pune, Maharashtra, India for providing financial assistance (BCUD Project Grant) for the present research work. The authors are also thankful to the Management of MAEER's Maharashtra Institute of Pharmacy, Pune.

\section{REFERENCES}

CHAO, Y.; ZHENGYU, J.; XUEMING, X.; HAINING, Z.; WANGYANG, S. Preparation and stability of the inclusion complex of astaxanthin with hydroxypropylbetacyclodextrin. Food Chem., v.109, p.264-268, 2008.

CUTRIGNELLI, A.; LOPEDOTA, A.; TRAPANI, A.; BOGHETICH, G.; FRANCO, M.; DENORA, N.; LAQUINTANA, V.; TRAPANI, G. Relationship between dissolution efficiency of Oxazepam/carrier blends and drug and carrier molecular descriptors using multivariate regression analysis. Int. J. Pharm., v.358, p.60-68, 2008.
FRIEDRICH, H.; NADA, A.; BODMIER, R. Solid state and dissolution rate characterization of co-ground mixtures of nifedipine and hydrophillic carriers. Drug Dev. Ind. Pharm., v.31, p.719-728, 2005.

HIGUCHI, T.; CONNORS, K. Phase solubility techniques. $A d v$. Anal. Chem. Instr., v.4, p.117-212, 1965.

HIROYUKI, O.; ATSUO, M.; TAKUROU, K.; YUJI, M.; YASUNORI, I.; TAKASHI, S.; SHIGERU, I. Freezedried nifedipine-lipid nanoparticles with long-term nanodispersion stability after reconstitution. Int. J. Pharm., v.377, p.180-184, 2009.

JAGDALE, S.; AGAVEKAR, A.; PANDYA, S.; KUCHEKAR, B.; CHABUKSWAR, A. Formulation and evaluation of gastroretentive drug delivery system of propranolol hydrochloride. AAPS Pharm. Sci. Tech., v.10, p.1071-1079, 2009.

JAGDALE, S.; KUCHEKAR, B.; CHABUKSWAR, A; MUSALE, V.; JADHAO, M. Preparation and in vitro evaluation of Allopurinol-Gelucire 50/13 solid dispersions. Int. J. Adv. Pharm. Sci., v.1, p.60-67, 2010.

KIMURA, S.; IMAI, T.; OTAGIRI, M. Pharmaceutical evaluation of Ibuprofen syrup containing low molecular weight gelatin. J. Pharm. Sci., v.81, p.141-144, 1992.

KORSEMEYER, R.; GURNY, R.; DOELKER, E.; BURI, P.; PEPPAS, N. Mechanism of Solute release from porous hydrophilic polymers. Int. J. Pharm., v.15, p.25-35, 1983.

KUCHEKAR, B.; ARUMUGAM, V. Fast dissolving tablets. Ind. J. Pharm. Edu., v.35, p.150-154, 2001.

LACHMAN, L.; LIEBERMAN, H.A.; KAING, J.L. The theory and practice of industrial pharmacy. 4.ed. New Delhi: CBS Publication, 1991. p.66-99.

MARAIS, A.; SONG, M. Effect of compression force, humidity and disintegrant concentration on the disintegration and dissolution of directly compressed furosemide tablets using croscarmellose sodium as a disintegrant. Trop. J. Pharm. Res., v.2, p.125-135, 2003. 
NALLURI, B.; CHOWDARY, K.; MURTHY, K.; SATYANARAYANA, V.; HAYMAN, A.; BECKET, G. Inclusion complexation and dissolution properties of nimesulide and meloxicam-hydroxypropyl-b-cyclodextrin binary systems. J. Incl. Phen. Macrocyclic Chem., v.53, p.103-110, 2005.

NAVEEN, A.; KATARE, O.; SINGH, B. Studies on dissolution enhancement and mathematical modeling of drug release of a poorly water-soluble drug using water-soluble carriers. Eur. J. Pharm. Biopharm., v.65, p.26-38, 2007.

PATIL, J.; PANDYA, N.; MARAPUR, S.; SHIRALASHETTI, $\mathrm{S}$. Influence of method of preparation on physicochemical properties and invitro drug release profile of nimodipine cyclodextrin inclusion complexes: a comparative study. Int. J. Pharm. Sci., v.2, p.71-81, 2010.

PITHA, J.; MILECKI, J.; FALES, H.; PANNELL, L.; UEKAMA, K. Hydroxypropyl- $\beta$-cyclodextrin: preparation and characterization; effects on solubility of drugs. Int. J. Pharm., v.29, p.73-82, 1986.

RAMANA, M.V.; HIMAJA, M.; DUA, K. A new approach: enhancement of solubility of rofecoxib. Asian J. Pharm., v.2, p.96-101, 2008.

SETTY, M.C.; PRASAD, D.; GUPTA, V. Development of fast dispersible aceclofenac tablets: effect of functionality of superdisintegrants. Ind. J. Pharm. Sci., v.70, p.180-185, 2008 .
SHIRSAND, S.; SARASIJA, S.; SWAMY, P. Formulation design and optimization of fast dissolving clonazeapm tablet. Ind. J. Pharm. Sci., v.71, p.567-572, 2009.

SHIRSAND, S.; SARASIJA, S.; SWAMY, P.; KUMAR, D.; RAMPURE, M. Design and evaluation of fast dissolving tablets of clonazepam. Ind. J. Pharm. Sci., v.70, p.791-795, 2008.

TSINONTIDES, S.; RAJNAIK, P.; PHAM, D.; HUNKE, W.; PLACEK, J.; REYNOLDS, S. Freeze drying-principles and practice for successful scale up to manufacturing. Int. J. Pharm., v.280, p.1-16, 2004.

UNITED STATES PHARMACOPOEIA. Asian Edition. Rockville: United States Pharmacopeial Convention, 2009. v.1, p.725-726.

VAN, G.; AUGUSTIJnS, P.; BLATON, N.; KINGET, R. Physico-chemical characterization of solid dispersions of temazepam with polyethylene glycol 6000 and PVP K30. Int. J. Pharm., v.164, p.67-80, 1998.

VANSHIV, S.; RAO, R. Physicochemical characterization and in vitro dissolution of Oxcarbazepine and $\beta$-cyclodextrin inclusion complexes. Ind. Drug, v.45, p.816-820, 2008.

Received for publication on $4^{\text {th }}$ July 2011 Accepted for publication on $16^{\text {th }}$ December 2011 